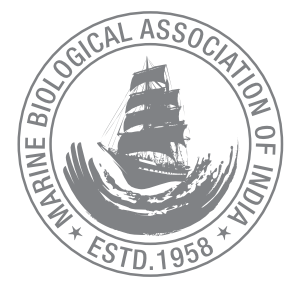

\title{
Status and conservation issues of window pane oyster Placuna placenta (Linnaeus 1758) in Kakinada Bay, Andhra Pradesh, India
}

\author{
P. Laxmilatha \\ Central Marine Fisheries Research Institute, P. B. No. 1603, Ernakulum North P.O., Cochin 682 018, Kerala, India. \\ *Correspondence e-mail: laxmil@yahoo.com
}

Received: 27 Apr 2015, Accepted: 27 Jun 2015, Published: 30 Jun 2015

Short Communication

\begin{abstract}
The Kakinada Bay in Andhra Pradesh, India is a rich ground of the pearl bearing window pane oyster, Placuna placenta. The total window pane oyster landing during 2011-2012 was 461.3 t; the total effort 13,777 man days and mean catch per unit effort (CPUE) 29.7 $\mathrm{kg}$. The mean landing was $230.7 \mathrm{t}$ and mean effort was 6,889 . The window pane oyster is protected under Schedule IV of the Indian Wildlife Protection Act, 1972; however, clandestine fishing for live as well as fossilized shells of the window pane oyster occurs in the Kakinada Bay. This is highly detrimental to the stock of the window pane oysters in the Bay. The present status of the exploitation of the window pane oyster in the Kakinada Bay is assessed. The need to protect the species is highlighted and management and conservation measures are discussed.
\end{abstract}

Keywords: Window pane oyster Placuna placenta, Kakinada Bay, status, management, conservation.

\section{Introduction}

The windowpane oyster, Placuna placenta, also known as "Kapis", is a bivalve marine mollusc in the family Placunidae. It is found in the Gulf of Aden, around India, the Malay Peninsula, the southern coasts of China and along the northern coasts of Borneo to the Philippines (Yonge, 1977). The major producer of "kapis" is Phillipines which exported US \$ 36 million worth of "kapis" products between 1986and 1991 (Gallardo et al., 1995). In India, the window pane oyster is distributed in the Gulf of Kutch (Gujarat) (Hornell, 1909a, b; Moses, 1939, 1947; Varghese, 1976), Kakinada Bay (Andhra Pradesh) and Nauxim Bay (Zuari estuary in Goa) and the Tuticorin Bay and Velapatti near Tuticorin (Tamil Nadu) (Dharmaraj and Sreenivasagam, 2002). P placenta is found on muddy or sandy substrata from shallow water to depths of $100 \mathrm{~m}$.

The Kakinada Bay in Andhra Pradesh is a rich ground of live window pane oyster as well as dead shells (Murthy et al., 1979; Radhakrishna and Ganapati, 1967; Narasimham, 1973; Sarvaiya, 1977; Narasimham et al., 1984). The pearl yield of windowpane oyster in the fishery was about $98 \mathrm{~kg}$ at an estimated yield of $1 \mathrm{~kg}$ per $51 \mathrm{t}$ of window pane oysters (Murty and Narasimham, 1979). The occurrence of pearls in $P$ placenta was reported by Bhavanarayana and Raghunath 
(1973) and Achutankutty et al. (1979). The pearls are used in the pharmaceutical preparations of medicines. The shell is large, very flat, thin and rounded. The inner surface is smooth, glossy and has a brilliant pearly iridescence. The shell can be made into beautiful handicrafts like windowsills, lampshades, flower vases, chandeliers, coasters, wind chimes, wall panels and many other decorative accessories. The shell is also used for the preparation of lime. The meat of the window pane oyster is very meager; however it is edible due to its high protein content and is consumed in certain communities (Ingole and Clemente, 2006).

Hornell $(1909 a, b)$ was the first to report on the prospects of pearl fisheries, the anatomy, distribution and economic uses of Placuna placenta. The 'Kapis' is an important fishery in Philippines and ranks fifth in the fishery exports (Philippines fisheries profile, 1991). Farming of window pane oysters was carried out in the late 1950's on the tidal flats of Bacoor Bay (Blanco, 1958). The biology and ecology of this species has been studied by Rosell (1979). Induced spawning, embryonic and larval development (Madrones-Ladja,1997; Young,1980; Dharmaraj et al, 2004), effect of salinity on embryonic development, larval growth and survival (Madrones-Ladja, 2002a) and effect of micro algal diet and rearing condition on gonad maturity in $P$ placenta (Madrones-L (2002 b) has been studied.

The window pane oyster is protected under Schedule IV of the Indian Wildlife Protection Act, 1972; however, clandestine fishing for live as well as fossilized shells occurs in the Kakinada Bay. The present status of the exploitation of the window pane oyster in the Kakinada Bay is assessed. The need to protect the species is highlighted and management and conservation measures are discussed.

\section{Material and methods}

The Kakinada Bay, spreading over an area of $146 \mathrm{~km}^{2}$ is situated between $16^{\circ} 51^{\prime}-17^{\circ} \mathrm{N}$ and $81^{\circ} 15^{\prime}-81^{\circ} 22^{\prime} \mathrm{E}$, in Andhra Pradesh State, India. It opens into the Bay of Bengal on its northern side and is bordered by mainland on the western side, by mangrove forests on southern side and by a narrow sand bar called Hope Island, on its eastern side. The Kakinada (upputeru) canal, Chollangi canal, Matlapalem canal Coringa river and Pillavarava creek, which are connected to the Gautami branch of the Godavari river, open into the Bay. The Bay is shallow and large mud flats are exposed during low tides, on the southern and western sides. The maximum depth in the bay is 6.8 meters (Narasimham, 1973; Narasimham, 2004). The window pane oyster is distributed in about $40 \mathrm{~km}^{2}$ area along the western and south central regions of the Bay.
The catch and effort data of the window pane oyster fished from the Kakinada Bay was collected for 2 years (2011-2012) from the Chollangi and Peddavalsala landing centers of Kakinada Bay at fortnightly intervals and monthly production was estimated for the month based on the number of fishing days. Diameter and shell height of 50 oysters were recorded to analyze the length frequency and biometrics. Details regarding fishing, utilization and price were collected through observations and enquiry.

\section{Results}

\section{Fishery}

The window pane oysters are collected from the Kakinada Bay at low tides. The maximum depth at low tide is $2 \mathrm{~m}$ in the fishing ground. Fishermen from 15 villages are involved in the fishery. In all, 40 men, 32 women and 90 children are involved in the collection of bivalves and gastropods from the Kakinada Bay. They collect over a dozen species of molluscs of which P. placenta and the blood clam Anadara granosa are the most dominant. Men, women and children are involved in the fishing. Women and children hand pick the molluscs in the intertidal zone. Two types of crafts are used in this fishery, Nava and shoedhoni and 3-8 divers dive and hand pick the oysters.

Placuna placenta collection (though banned) is carried out clandestinely and stocked inside the Forest area until putrificaton. As and when traders from Yanam or Pedavalasa request for the shells, the fishermen are informed and they transport the shells through the Bay by motorized fibre boat or Kakinada Nava to the respective areas.

The total window pane oyster landing during 2011-2012 was $461.3 \mathrm{t}$; the total effort 13,777 at mean catch per unit effort (CPUE) $29.7 \mathrm{~kg}$. The mean landing was $230.7 \mathrm{t}$ and mean effort was 6,889 . The annual landing of window pane oyster during 2011 was $404.9 \mathrm{t}$, effort 8212 and CPUE $49.31 \mathrm{~kg}$. The annual landing of window pane oyster during 2012 was 56.4 $\mathrm{t}$, effort 5,565 and CPUE $10.13 \mathrm{~kg}$. The monthly landings of the window pane oyster (Fig. 1) show that maximum landings were recorded during August to November period in 2011 while significant landing was recorded only during May 2012. A drastic decline (86 \%) in the landings occurred in 2012; the effort also declined by $32 \%$.

Clandestine exploitation of live oysters as well as fossilized shells occurs in the Bay. The shells (Fig. 2) are dredged from the upper reaches of the Bay and canoe loads are transported through the Kakinada Bay to Yanam (Union Territory of Pondicherry). The shells are then flushed of mud and debris and washed thoroughly. They are sun dried and packed in 


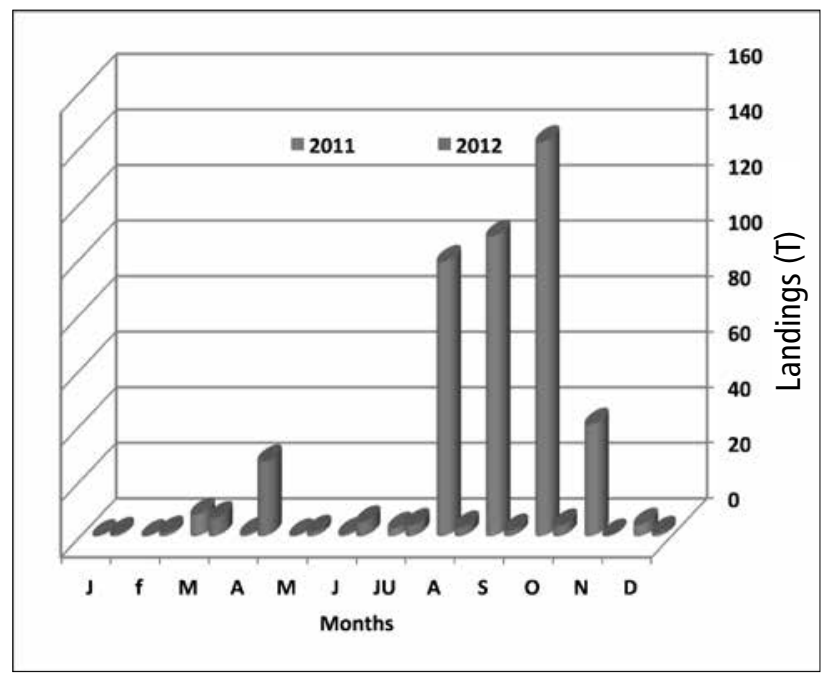

Fig. 1. monthly landings of Placuna placenta during 2011-2012.

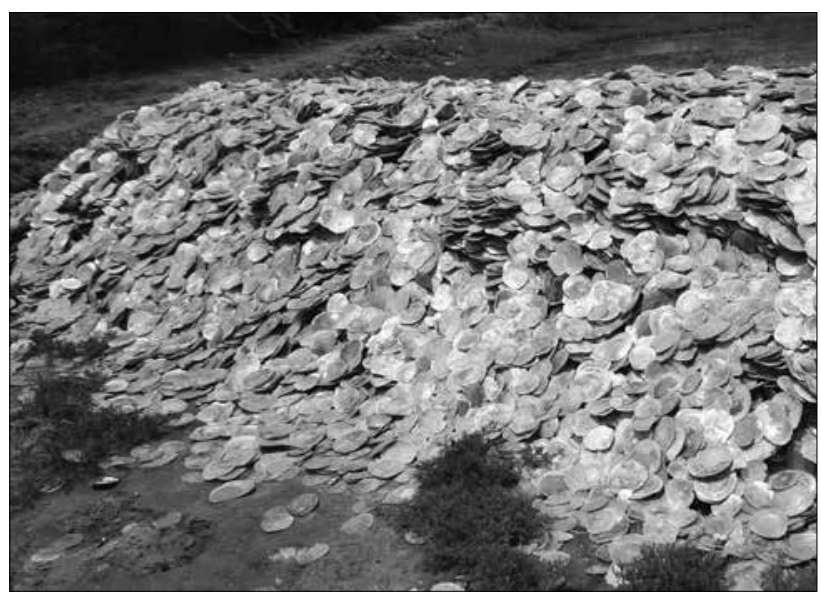

Fig. 2. P. placenta exploited from the Kakinada Bay.

gunny bags and loaded onto trucks for transportation to neighboring States of Tamil Nadu and Maharashtra.

\section{Length - width relationship}

The length of the window pane oysters exploited from the bay ranged from 70 to $146 \mathrm{~mm}$ and the width (diameter) ranged from 77 to $154 \mathrm{~mm}$. The modal length class ranged from 120 to 135 while the modal width class ranged from 125 to 140 (Fig. 5). The length-width relationship was given by $\log Y$ $=-1.808188+0.883086 \log X(r=0.894)$ (Fig. 6) and the width on length relationship was given by $\log Y=-1.511156$ $+0.905528 \log X(r=0.894)$. The growth coefficient ' $b$ ' in both cases was less than 1, indicating that the growth is negatively allometric in the window pane oyster.

\section{Discussion}

P. placenta is one of the most important bivalve resources in the Kakinada Bay. The landings increased from $9 \mathrm{t}$ in 1988

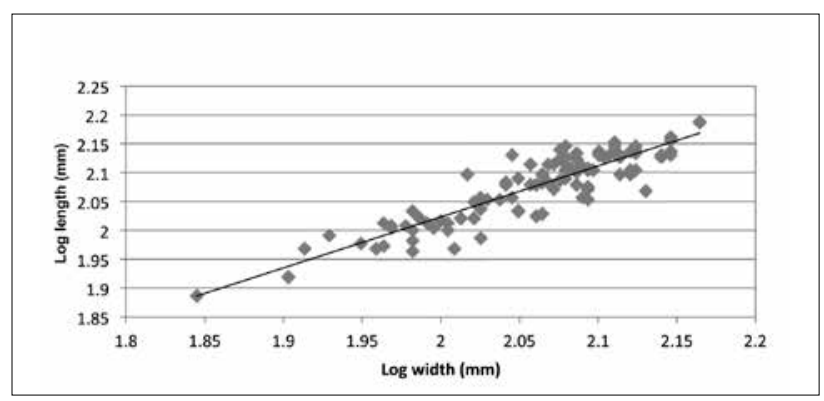

Fig. 3.Length-width relationship of Placuna placenta.

to $140 \mathrm{t}$ in 1993 (Syda Rao and Somayajulu, 1996). The size range of 90-120 mm occurred in the fishery (Syda Rao and Somayajulu, 1996) while the present size is $70-146 \mathrm{~mm}$. The stock of $P$. placenta in the Kakinada Bay was estimated at 9,000 $\mathrm{t}$ and dead oyster shells at 43,000 $\mathrm{t}$ (Murthy et al., 1979) and at 12,500 t (Syda Rao and Somayajulu, 1996). Based on population dynamics of $P$. placenta during 199881, Narasimham (1987) stated that there was no danger of exploitation through recruitment overfishing even at higher levels of fishing mortality. However, the present landings of $461 \mathrm{t}$ (2011-12) indicate a drastic decline in the stock as a result of excessive clandestine exploitation (Syda Rao and Somayajulu, 1996).

The clandestine exploitation of live oysters and fossil shells is flourishing despite protection given under the Schedule I of the Wildlife Protection Act (WPA) (1972). Major part of the Kakinada Bay is in the Corringa wildlife sanctuary and the beds of the window pane oysters are spread out in this area. Strict monitoring and regulation is not being implemented to curb the illegal and clandestine exploitation of live oysters as well as fossil shells in the Nauxim Bay, Goa. Although, 8,00010,000 window pane oysters of 18-131 mm size are fished every day, the oyster population remains healthy and similar to that recorded by Achutankutty (1979) with good number of pearls (Ingole and Clemente, 2006). In Phillipines, the "Kapis" were being overexploited since 1970's due to increased world demand. This has also led to several destructive methods of fishing; siltation and pollution also contributed to the decline in population (Gallardo et al., 1995). In Philippines, an

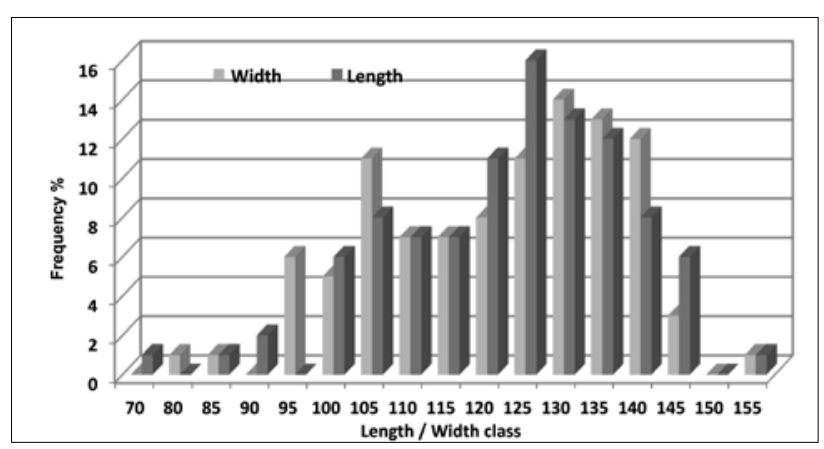

Fig. 4. Length/width frequency $\%$ of window pane oyster. 
ordinance to protect this species was promulgated in 1986 (Gallardo et al., 1995, http://www.bfar.da.gov.ph/legislation/ fao/fao157.html), yet overfishing has led to depletion of stock (Alimen and Selorio, 2013).

\section{Management and conservation plan}

The window pane oyster exploitation needs to be more strictly monitored and regulated. A holistic Shellfish Fisheries Management Plan (SFMP) needs to be implemented for the sustainable exploitation of the diverse bivalve and gastropod resources in the Bay. Setting up an exclusive protected area (MPA)/sanctuaries, for the window pane oysters will ensure conservation and protection to this endangered species. Hatchery seed production methods have been standardized (Young 1980, Madrones-Ladja and de la Peña, 2000., Dharmaraj et al., 2004) and therefore, establishment of window pane oyster hatcheries for the replenishment of wild stock with hatchery produced spat will facilitate stock enhancement. Utilization of window pane oysters for research and seed production must be permitted to conserve the window pane oysters (http://www.seafdec. org.ph/stories/story06-stock-enhancement-program.html). Participation of the local fishers (dependent on Kapis fishing for their livelihood), fisheries and wild life department officials' researchers and other government officials in the comanagement and conservation activities is urgent need of the hour to protect and conserve this species of high economic and ecological value.

\section{Acknowledgements}

The author is thankful to the Director, Central Marine Fisheries Research Institute for support and encouragement in carrying out this work. The technical assistance rendered by Shri. Dhanaraj in collecting the landings data is appreciated and acknowledged.

\section{References}

Achutankutty, C. T., S. R. S. Nair and M. Madhupratap. 1979. Pearls from the window pane oyster Placuna placenta. Mahasagar, 12:187-189.

Alimen, R. A and C. M. Jr. Selorio. 2013. Status of window pane oysters (Placuna placenta) at Municipality of Tigbauan, lloilo, Philippines. IAMURE Intl. J. Ecol. Conserv., 5: 2244-1573 doi: http://dx.doi.org/10.7718/ijec.v5i1.509.

Bhavanarayana, P. V. and B. Raghunath. 1973. On the occurrence of pearls in Placenta placenta (Linne). Curr. Sci., 42: 859.

Blanco, G. (1958). Kapis farming at the tidal flats of Bacoor Bay, Luzon, Philipp. J. Fish., 6: 9-15.

Dharmaraj, S and M. K. Sreenivasagam. 2002. Exploitation of windowpane oyster Placuna placenta Linnaeus at Vellapatti area near Tuticorin. Mar. Fish. Infor. Serv. T\&E Ser., 174: 9.

Dharmaraj, S., K. Shanmugasundaraman and C. P. Suja. 2004. Larval rearing and spat production of the windowpane shell Placuna placenta. Aquaculture Asia, 9: 20-28.
Gallardo, W. G., S. V. Siar and V. Encena, II. 1995. Exploitation of the Window Pane shell Placuna placenta in the Philippines. Biological Conservation, 73: 33-38.

Hornell, J. 1909a. Report to the Government of Baroda, on the prospects of establishing a pearl fishery and other marine industries on the coast of Okhamandal. Report to the Government of Baroda on the Marine Zoology of Okhamandal in Kathiawar. Williams and Norgate, London, 1-34.

Hornell, J. 1909b. Report on the anatomy of Placenta placenta, with notes on its distribution and economic uses. Report to the Government of Baroda on the Marine Zoology of Okhamandal in Kathiawar. Williams and Norgate, London, 43-97.

http://www.seafdec.org.ph/stories/story06-stock-enhancement-program.html.

http://www.bfar.da.gov.ph/legislation/fao/fao157.html.

Ingole, B. S. and S. Clemente. 2006. Status of Windowpane oyster Placuna placenta (Linnaeus) population in Goa, In.Glimpses of Marine Archaeology in India, Edited by A. S. Gaur and K. I. Vera. Published by Society for blarit e Archaeology.

Madrones-Ladja, J. A. 1997. Notes on the induced spawning, embryonic and larval development of the window pane-shell, Placuna placenta (Linnaeus, 1758), in the laboratory Aquaculture, 157: 137-146.

Madrones-Ladja, J. A. 2002. Salinity effect on the embryonic development, larval growth and survival at metamorphosis of Placuna placenta Linnaeus (1758) Aquaculture, 214: 411-418.

Madrones-Ladja, J. A., M. R. de la Pena and N. P. Parami. 2002. The effect of micro algal diet and rearing condition on gonad maturity, fecundity and embryonic development of the window pane shell, Placuna placenta Linnaeus. Aquaculture, 206: 313-321.

Madrones-Ladja, J. A and M. R. de la Peña. 2000. Hatchery management for the window-pane shell, Placuna placenta Linnaeus 1758. Phuket. Mar. Biol. Cent. Spec. Publ., 21(1): $189-194$.

Moses, S. T. 1939. The recent Placuna pearl fishery in Baroda and some notes on the window-pane oyster. J. Bombay. Nat. Hist. Soc., 41: 119-122.

Moses S. T. 1947. Pearls and pearl fishery in Baroda state; Placenta placenta the source of pearls in Baroda. Bull. Dept. Fish. Baroda, 12: 1-11.

Murthy, V. S. R., K. A. Narasimham and W. Venugopalan. 1979. Survey of windowpane oyster (Placenta placenta) resources in the Kakinada Bay. Indian J. Fish., 26(1\&2): 25-132.

Narasimham, K. A. 1973. on the moluscan fisheries of the Kakinada Bay. Indian J. Fish., 20: 209-214.

Narasimham, K. A. 1987. fishery and dynamics of the window pane oyster, Placenta placenta (Linnaeus), from Kakinada Bay. Indian J. Fish., 34(3), 277282.

Narasimham, K. A. 2004. Molluscan fisheries of Kakinada Bay-Recent developments. Proceedings of the Seminar on Sir Arthur Cotton's vision on River water Management for Food security. Organised by SastriyaVignanaSamithi and SPICAM , Kakinada 15th May 2004, p 69-73.

Narasimham, K . A., G. S. D. Selvaraj and S. Lalitha Devi. 1984. The mollscan resources and ecology of Kakinada Bay. Mar. Fish. Infor. Ser. T\& E Ser., No 59, 1-15.

Philippine Fisheries Profile 1985-1991. Bureau of Fisheries and Aquatic Resources, Manila.

Radhakrishna, Y. and P. N. Ganapati. 1967. Fauna of the Kakinada Bay. Bull. Nat. Ins. Soc. India, 38:689-699.

Rosell, N. C. (1979) A study on the biology and ecology of Placuna placenta Linne. Appl. Sci. Bull., 31(3-4):203-51.

Sarvaiya, R. T. 1977. Studies on Mollusca of Saurashtra Coast-II (Pelecypoda) Fish Technol., 14: 27-32.

Syda Rao, G. and K. R. Somayajulu. 1996. Resource characteristics of exploited bivalves and gastropods of Kakinada Bay with a note on stock assessment Mar. Ser. Info. Ser. T\& Eser., 14:13-19.

Varghese, M. A. 1976. Window-pane oyster (Placenta placentalinn) of the Gulf of Ku'tch Seafood Exp., J8: 25-28.

Yonge C. M. 1977. Form and evolution in the Anomiacea (Mollusca: Bivalvia) Pododesmus Anomia, Patro, Enigmonia (Anomiidae); Placunanomia, placuna (Placunidae, Fam. Nov.) Philosophical Transactions of the Royal Society of London B, 276: 453-527.

Young A. L. 1980. Larval and post larval development of the windowpane shell, Placuna placenta Linnaeus (Bivalvia: Placunidae) with a discussion on its natural settlement Veliger, 23(2):141-148. 